\title{
Down's syndrome, neuroinflammation, and Alzheimer neuropathogenesis
}

\author{
Donna M Wilcock ${ }^{1}$ and W Sue T Griffin ${ }^{2,3^{*}}$
}

\begin{abstract}
Down syndrome (DS) is the result of triplication of chromosome 21 (trisomy 21) and is the prevailing cause of mental retardation. In addition to the mental deficiencies and physical anomalies noted at birth, triplication of chromosome 21 gene products results in the neuropathological and cognitive changes of Alzheimer's disease (AD). Mapping of the gene that encodes the precursor protein (APP) of the $\beta$-amyloid (A $\beta$ ) present in the A $\beta$ plaques in both $A D$ and DS to chromosome 21 was strong evidence that this chromosome 21 gene product was a principal neuropathogenic culprit in AD as well as DS. The discovery of neuroinflammatory changes, including dramatic proliferation of activated glia overexpressing a chromosome 2 gene product - the pluripotent immune cytokine interleukin-1 (IL-1) - and a chromosome 21 gene product - S100B - in the brains of fetuses, neonates, and children with DS opened the possibility that early events in Alzheimer pathogenesis were driven by cytokines. The specific chromosome 21 gene products and the complexity of the mechanisms they engender that give rise to the neuroinflammatory responses noted in fetal development of the DS brain and their potential as accelerators of Alzheimer neuropathogenesis in DS are topics of this review, particularly as they relate to development and propagation of neuroinflammation, the consequences of which are recognized clinically and neuropathologically as Alzheimer's disease.
\end{abstract}

\section{Introduction}

Down syndrome (DS), trisomy 21 , is the most common chromosomal defect, with an incidence in the United States of one per seven-hundred and thirty-three live births [1] with the rate of spontaneous abortions among trisomy 21 fetuses being 7 -fold that among non-trisomic fetuses. Not only is trisomy 21 the most frequent cause of mental retardation $[2,3]$, due to the extensive number of chromosome 21 genes [4], there is an extremely high incidence of congenital anomalies such as important cardiac and gastrointestinal malformations in trisomy 21 [5]. In the brain, neuritic amyloid- $\beta(A \beta)$ plaques - a characteristic neuropathological feature of Alzheimer's disease $(\mathrm{AD})$ - are a virtually certain finding in adults with DS [6-8] and have been noted in some children with DS [9]. For instance, among 12 children with DS, two

\footnotetext{
* Correspondence: griffinsuet@uams.edu

${ }^{2}$ Donald W. Reynolds Department of Geriatrics, Donald W. Reynolds Institute on Aging, University of Arkansas for Medical Sciences, 629 Jack Stephens Dr., Little Rock, AR 72205, USA

${ }^{3}$ The Geriatric Research Education Clinical Center, Central Arkansas HealthCare System, Little Rock, AR, USA

Full list of author information is available at the end of the article
}

(ages 8 and 9 years) had $\mathrm{A} \beta$ plaques, and among those between the ages of 35 and 45 years, all had neuritic $A \beta$ plaques and other $\mathrm{AD}$ pathologies, such as neurofibrillary tangles and glial activation. Although the prediction of $\mathrm{AD}$ neuropathological changes at middle age is reported to be a virtual certainty in those with DS, predictions regarding timing of the onset of dementia are less certain, with estimates of approximately 50 to $70 \%$ of individuals with DS developing dementia by age 60 to 70 years [10-15].

Identification and characterization of early events that contribute to and or regulate the expression of chromosome 21 gene products that are triplicated in DS is vital if we are to understand the ways in which neurodegenerative cycles and the mechanisms they employ in promotion of the neuropathophysiological progression of sporadic $\mathrm{AD}$ and of $\mathrm{AD}$ in DS. Three such early events have been reported in DS fetuses and each is related to the others as they induce, and are induced by each other and by cytokines subsequent to neuroinflammatory changes. In particular, these include overexpression of two chromosome 21 gene products - APP [16] and S100B [17] - and the resultant overexpression of the pluripotent neuroinflammatory cytokine IL-1 [17], which is encoded 
by chromosome 2 genes $I L-1 A$ and $I L-1 B[18,19]$. Complex interactions between APP, glial activation, S100B, and IL-1 include upregulation of the expression of IL- $1 \alpha$ and $\beta$ by both APP [20] and S100B [21,22], and induction of both APP and S100B by IL-1 $\beta$ [23]. Such interactions have been shown to be elicited by multiple neural insults, each of which is characterized by gliosis-related neuroinflammation and risk for development of the characteristic neuropathological changes of AD [24].

It is now more than twenty years since the report of prominent glial activation with excessive expression of inflammatory cytokines such as the chromosome 21 gene product S100B and the chromosome 2 gene product IL-1 in DS fetuses, infants, children, and adults in DS, and in AD $[17,25]$. Such glial activation and cytokine overexpression occurs years before the virtually certain appearance at middle age of the A $\beta$ plaques in DS [14]. Accompanying reports demonstrated that IL-1 induces the synthesis of APP in non-neural and neural cells $[21,26]$; this IL-1 induction of APP was later verified in neurons in in vitro and in vivo studies that included evidence of IL-1 induction of S100B [23]. As evidence that glial activation and neuronal expression of APP are potentially self-propagating events, IL-1 and S100B both induce microglial and astrocytic activation with overexpression of themselves, as well as of neuronal APP $[23,27]$. This idea was supported by reports from Barger [20] and Li et al. [28] of neuronal stress-induced excessive expression of neuronal APP and elevated release of sAPP, which, in turn, activates microglia and induces their overexpression of IL-1 $\beta$ [20]. Taken together, these reports suggest that glial activation and resulting cytokine overexpression contribute to APP overexpression and in so doing may favor the appearance of $A \beta$ plaques in children with DS. In DS, then, it may be sufficient to merely invoke gene load-related upregulation of neuronal APP and astrocytic S100B as seminal events that may drive neuronal stress, glial activation, and DS-related neuropathological changes characteristic of AD.

Experimental evidence supports the idea that excessive levels of cytokines such as IL-1 and S100B are key factors in development of the neuropathological changes of $\mathrm{AD}$. For instance in the presence of excess IL-1, whether in brains of experimental animals or in purified rodent neurons in cultures, APP is overexpressed [23,29]. It is logical to assume that in situ glial activation with excess IL- $1 \beta$ would favor genesis and progression of $A \beta$ plaque maturation [30], increases in synthesis and phosphorylation of the MAPK-p38 necessary for production of hyperphosphorylated tau and neurofibrillary tangle formation [31]. Such neuroinflammatory consequences are consistent with the idea that any entity, which acts to precipitate changes that lead to genesis of the same entity, may become a self-propagating cycle and thus has the potential to become chronic. If so, neuropathogenesis is, at least in part, the result of self-propagating cycles [32]. By analogy, without regard to the diversity of the source of neuronal stress, for example, traumatic brain injury [33], epilepsy [34-36], aging [37,38], or AIDS [39], the downstream consequence is increased risk for development of the neuropathological changes of $\mathrm{AD}$ marked by increased expression of neuronal APP $[36,40]$, activation of glia, and neuroinflammatory cytokine expression [20]. Accordingly, exaggeration of such neuronal-glial interaction due to trisomy $21[7,24,32]$ would be expected to culminate in neuropathogenic cycles that favor the progression in DS of the neuropathological changes of $\mathrm{AD}$.

The danger of chronic induction of neuroinflammation with its manifestation of glial activation and cytokine overexpression is related to the capacity of proinflammatory cytokines such as IL- $1 \beta$ to self-propagate as they, themselves, activate microglia and astrocytes and further excess expression of IL-1 $\beta$. In addition to IL- $1 \beta$ induction of the precursors of the principal neuropathological changes in AD, viz., APP [23] for A $\beta$ plaques, S100B for non-sensical growth of dystrophic neurites in plaques [41], synthesis and activation of MAPK-p38 for hyperphosphorylation of tau $[42,43]$, favors formation of neurofibrillary tangles. In addition to favoring formation of these anomalies, IL- $1 \beta$ induces the synthesis and the activity of acetylcholinesterase, thus favoring the breakdown of acetylcholine [28], an important neurotransmitter in learning and memory [44], which is known to be decreased in AD [45,46]. Similarly devastating, excess IL-1 $\beta$, as observed in $\mathrm{DS}$ and $\mathrm{AD}$, is associated in vitro and in vivo with decreases in the expression of synaptophysin [31], which is a hallmark of the synaptic loss in AD $[47,48]$. Such neuropathophysiological changes would be expected to further stress neurons, promote more neuroinflammation, and in this way create a self-propagating cycle [40] of ever increasing neuronal stress, dysfunction, and loss [49].

Microglia, regarded as the principal cells of the brain's innate immune system, were first identified as a unique glial cell subtype in the second decade of the twentieth century by Pio del Rio Hortega [50] and were later identified immunohistochemically using macrophage cell surface markers [51,52]. In the second to the last decade of the century, microglia were shown to be a primary source of the pluripotent immune cytokine IL-1, and this together with the astrocyte-derived neuritogenic cytokine S100B, were held to be responsible for neuroinflammatory responses in very early stages of the development of DS, and by analogy, perhaps in $\mathrm{AD}$ [17]. More recently, astrocytes and neurons as well as oligodendrocytes and vascular pericytes have been recognized as participants in cytokinerelated neuroinflammatory processes [53].

In $\mathrm{AD}$, microglia expressing some classic activation markers such as major histocompatibility complex 
(MHC-II) (associated with antigen presentation), CD68 (a lysosomal protein) and CD36 (a class B scavenger receptor) are highly localized to the area immediately surrounding an amyloid plaque or neurofibrillary tangle [54]. While this led some to hypothesize that microglial activation was contributing to the pathology, others proposed they performed a beneficial function in removing $\mathrm{A} \beta$ from the brain [55]. On the one hand, correlation between the overexpression of IL- $1 \alpha$ in such plaqueassociated microglia with plaque formation and progression from immature deposits to mature senile plaques suggests that microglia contribute to formation and progression of $\mathrm{A} \beta$ plaques from deposits to mature senile plaques $[30,37,38,56]$. Similarly, overexpression of IL- $1 \alpha$ in activated microglia adjacent to neurons bearing neurofibrillary tangles, as well as the role of IL-1 in promotion of hyperphosphorylated tau [31] suggests a role for activated glia and excess IL-1 in both the production of tangle substrate and in the progression from paired-helical, filamentous threads to non-neuronal, cell-shaped flames of neurofibrillary tangles [57].

\section{Chromosome 21 genes and neuroinflammation}

Triplication of even a small region (21q22.3) on the short arm of chromosome 21, which is referred to as the critical region (DSCR), is sufficient to result in the DS phenotype, prominently including mental retardation, and growth retardation, as well as muscle, joint, and facial features characteristic of DS [58-60]. Recognizing the importance of an extra copy of this precise region of chromosome 21 in the pathology of DS does not lessen the potential importance of triplication of those chromosome 21 genes, which are located outside this region, in neuropathogenesis. The APP gene does not map to the critical region of chromosome 21, but more than any other gene on chromosome 21, APP has played a seminal role in our understanding of neuropathological changes in $\mathrm{AD}$ and DS, as well as in neurological disorders that give rise to precocious development of AD (for review please see [49]). Steve Barger's discovery of a role for a secreted fragment of APP, SAPP, in synthesis and release of the pro-neuroinflammatory cytokine IL-1 [20], together with studies demonstrating the importance of IL-1 in promotion of neurodegenerative events [32], underscores the importance of APP, over and above its importance as the precursor of the $A \beta$ in the senile plaques characteristic of $A D$ and DS.

\section{APP}

Although the full significance of triplication of the APP gene in Alzheimer pathogenesis in DS is still under investigation, it is clear that there is a dramatic overexpression of the APP gene product in fetal DS [61], which is accompanied by a similarly dramatic increase in the levels of IL-1 and S100B [17], two neuroinflammation-promoting cytokines that are known to induce the overexpression of APP in vitro [21] and in vivo [23].

Glenner's report of sequence homology between the $A \beta$ peptide derived from brains of those with $A D$ or with DS was the first evidence linking $\mathrm{AD}$ to $\mathrm{DS}$, and the APP gene to chromosome 21 [62,63]. Although the $50 \%$ increase in APP expression that would be predicted as a consequence of gene loading $(1.5 \times)$ in trisomy, may not be sufficient to result in the characteristic pathophysiology of DS, but, together with its induction of IL-1 and the resultant increase in APP, may be responsible, at least in part, for the role of $A P P$ gene triplication as a determinant of the age at onset of dementia in DS [64] and in the development of the neuropathological changes of AD in DS [65]. In fact, triplication of the APP gene alone is associated with the development of early onset $\mathrm{AD}$ [65-67]. Findings such as these, together with the prominence of $\mathrm{A} \beta$ plaques in Alzheimer neuropathology, led to development of the Amyloid Hypothesis [68], which has served in many ways to expand our understanding of how APP expression could be related to the development not only the $A \beta$ plaque but to a range of the neuropathological features of $\mathrm{AD}$, including neurofibrillary tangles, glial activation, and overexpression of neuroinflammatory cytokines. However, concentration on $A \beta$ plaques and the Amyloid Hypothesis has to some degree led away from the importance of overexpression of APP, itself, in Alzheimer pathogenesis. For example, neuronal stress imposed by a variety of neurological conditions [32], which are associated with increased risk for development of AD, results in overexpression of APP, release of sAPP, glial activation, and overexpression of IL-1 for genesis of each of the precursors of the neuropathological changes of $\mathrm{AD}$, implying that overexpression of APP starts a cascade of events that gives rise to $A \beta$ deposition rather than $A \beta$ being seminal in Alzheimer pathogenesis. An interesting case that underscores the importance of APP overexpression in Alzheimer pathogenesis is that of a mildly retarded 78-year-old patient with partial trisomy 21 that did not include the $A P P$ gene sequence [69]. This patient, although of extremely advanced age for a person with DS, especially without the characteristic changes of $\mathrm{AD}$ [70], showed no clinical signs of dementia, and magnetic resonance imaging (MRI) 6 months before her death showed only minimal cerebral atrophy and no temporal lobe atrophy.

\section{BACE2}

Mapping of the chromosome 21 APP gene, from which is cleaved the $A \beta$ fragment present in plaques in DS and $\mathrm{AD}[61,71]$, together with the discovery of mutations in chromosome 21 genes that are linked to familial AD [71] and the virtual certain prediction of precocious development of $\mathrm{AD}$ present in those with trisomy 21 [14], 
lent credence to the importance of chromosome 21 genes in the development of $\mathrm{AD}$ [68]. This idea was reinforced by the mapping of the $\beta$-amyloid cleavage enzyme 2 (BACE2) to the DS critical region of chromosome 21 [72], which in concert with the $\gamma$-secretase complex is essential for cleavage of $A \beta 40$ and 42 from APP [73,74]. On the other hand, $\alpha$-secretase, which is not encoded on chromosome 21, plays an important function as it cleaves extracellular APP in the middle of the $A \beta$ portion, preventing release of $A \beta$ [75-77], acting as a neuroprotectant [78], and promoting activation of microglia and induction of synthesis and release of the proinflammatory cytokine IL-1 $\beta$ [20]. If BACE2 induced shedding of IL-1 receptor2 (IL-1R2) [79] acts to avail the brain of decoy receptors for IL-1, the levels of IL-1 may be reduced and therefore neuroinflammation responses in DS and AD dampened.

\section{S100B}

This astrocyte-derived cytokine is encoded by a chromosome 21 gene located in the DSCR [80]. It is markedly elevated during normal development [81] and is elevated throughout life in DS $[25,82]$. Its properties as a neurite extension factor [83] have been suggested as a contributor to normal growth and maintenance of neurons [84]. In excess, as in DS and AD, S100B is associated with marked nonsensical growth of dystrophic neuronal processes $[83,85,86]$, most notably in the neuritic $A \beta$ plaques diagnostic of $\mathrm{AD}[25,87,88]$.

Although S100B is important in development of the central nervous system (CNS) [89] and is protective of neurons from insults and promotes survival following injury [84], elevated blood levels of S100B serve as a marker indicative of stroke severity, survival, and progression from hemorrhage to acute thrombosis [90-92] as well as severity of traumatic brain injury [93]. Even seemingly minor head trauma in children and young adults is associated with elevated blood levels of S100B $[94,95]$. In addition to increased expression of S100B in activated astrocytes in neurological conditions, systemic diseases such as mild to severe liver disease is characterized by dramatic increases in astrocyte-derived S100B expression, encephalopathy, and cognitive decline [96,97].

\section{The role of APP and S100B in promoting neuroinflammation}

The dramatic increase in the expression of APP and $\mathrm{S} 100 \mathrm{~B}$ in DS suggests that (i) some gene product on chromosome 21 is dramatically inducing the APP and S100B synthesis in DS and or (ii) some chromosome 21 gene is indirectly inducing such excessive synthesis, via induction of a gene product on another chromosome, which, in turn, induces excessive expression of APP and S100B. Both of these possibilities have been validated in various cell types, including neuronal cells. For example in the first case, S100B induces the synthesis of neuronal
APP mRNA and the production of APP [27]. In the second case, Steve Barger provided the first evidence of a link between neuronal stress, APP expression, and neuroinflammation as he showed that the elevated release of the $\alpha$-secretase cleaved fragment, $\operatorname{sAPP} \alpha$, which accompanies the stress-induced increases in neuronal expression of APP, activates microglia and induces their expression of IL-1 $\beta$ [20]. Together then it may be concluded that both a chromosome 21 gene product, S100B [80], and a chromosome 2 gene product, IL-1 $\beta$, contribute to the elevation of APP expression in trisomy 21 to a much greater extent than that expected from gene loading.

Finding relationships between the overexpression APP, S100B, and IL-1 $\beta$ led to a series of experiments to explore mechanisms by which activation of glia and the resultant excess levels of neural IL- $1 \beta$ and S100B influence the neuropathogenesis of $\mathrm{AD}$, as well as the $\mathrm{AD}$ of $\mathrm{DS}$ [98]. This may be especially the case as such dramatic overexpression of APP as that in DS [61] would be predicted to promote self-propagating cycles of more and more production and release of neuroinflammatory cytokines IL-1 and S100B [17] and a resultant increase in APP. The neuronal strain of such dramatic induction of APP synthesis [99], together with challenges imposed by, for example $A \beta$ plaques [40] and or the presence of neuropathological changes such as neurofibrillary tangle formation have been shown to be accompanied by decreases in cellular expression of the total polyadenylated mRNA necessary for translation of the many proteins involved in cell functions [100].

\section{Other lesser-studied chromosome 21 gene products and their importance in neuroinflammatory processes}

Each of the chromosome 21 genes cited below encode (Table 1) gene products that also regulate expression of neuroinflammatory processes, and or are regulated by neuroinflammatory cytokines. Although their influence on neuroinflammation and its relation to neuropathogenesis is less studied than APP and S100B, their importance in such pathways should not be underestimated.

\section{CXADR}

The chromosome 21 gene that encodes the receptors for coxsackie virus and adenovirus (CXADR) acts as both a viral receptor and as an adhesion molecule associated with tight junctions. It is highly expressed in brain as well as systemic secretory organs such as the pancreas, testis, and small intestine [111]. In the absence of viral infection CXADR expression is elevated in models of myocardial inflammation. In view of triplication of the CXADR gene in trisomy 21 it will be interesting to discover whether there is a pro-inflammatory role for CXADR in the brain similar to that in the heart [112]. This is 
Table 1 A summary of the inflammation-related genes located on chromosome 21

\begin{tabular}{|c|c|c|c|}
\hline Gene & Protein & Function & Reference \\
\hline$\overline{\beta A P P}$ & $\begin{array}{l}\text { Amyloid beta precursor protein }>5 \text { fold overexpression } \\
\text { in DS }\end{array}$ & $\begin{array}{l}\text { Neuronal acute phase protein precursor of fragments } A \beta \text { in } \\
\text { Alzheimer plaques and sAPP for induction of } I L-1 \beta\end{array}$ & {$[16,20,63]$} \\
\hline BACE2 & $\beta$-site APP-cleaving enzymes-2 & $\begin{array}{l}\text { Cleaves APP for less A } \beta \text { and increases IL-1R2, a decoy protein } \\
\text { for excess IL-1 capture }\end{array}$ & [79] \\
\hline$S 100 B$ & $\begin{array}{l}\text { S100 calcium binding protein astrocyte-derived } \\
\text { cytokine }\end{array}$ & $\begin{array}{l}\text { Upregulates IL-1 } \beta \text { and } \beta A P P \text { expression, released in response } \\
\text { to TNFa }\end{array}$ & {$[22,27,82]$} \\
\hline CXADR & Coxsackie virus and adenovirus receptor & $\begin{array}{l}\text { Activation of JNK and p38-MAPK pathways leading to } \\
\text { production of M1 cytokines. }\end{array}$ & [101] \\
\hline ADAMTS1 & $\begin{array}{l}\text { ADAM metalloproteinase with thrombospondin } \\
\text { type } 1 \text { motif, } 1\end{array}$ & Secreted protease known to be induced by IL-1 $\beta$ & [102] \\
\hline ADAMTS5 & $\begin{array}{l}\text { ADAM metalloproteinase with thrombospondin } \\
\text { type } 1 \text { motif, } 5\end{array}$ & Secreted protease known to be induced by IL-1 $\beta$ and TGF $\beta$. & [103] \\
\hline TIAM1 & T-cell lymphoma invasion and metastasis 1 & $\begin{array}{l}\text { Necessary for cytokine- mediated generation of oxidative } \\
\text { species through NADPH oxidase. }\end{array}$ & [104] \\
\hline SOD1 & Superoxide dismutase 1 & Scavenges superoxide radicals producing $\mathrm{H}_{2} \mathrm{O}_{2}$ and $\mathrm{O}_{2}$. & [105] \\
\hline IFNAR2 & Interferon $a, \beta$, and $\omega$ receptor 2 & Activates JAKVSTAT mediated anti-inflammatory pathway & {$[106,107]$} \\
\hline IFNAR1 & Interferon $a, \beta$, and $\omega$ receptor 1 & Activates JAKVSTAT mediated anti-inflammatory pathway & [106] \\
\hline IFNGR2 & Interferon $\gamma$ receptor 2 & Activates JAK/STAT mediated anti-inflammatory pathway & [107] \\
\hline RIPK4 & Receptor-interacting serine-threonine kinase 4 & Necessary for signaling through TNFR1 & [108] \\
\hline CBS & Cystathione- $\beta$-synthase & $\begin{array}{l}\text { Catalyzes production of hydrogen sulfide }\left(\mathrm{H}_{2} \mathrm{~S}\right) \text { bimodal } \\
\text { regulation of inflammation }\end{array}$ & [109] \\
\hline PRMT2 & Protein arginine methyltransferase 2 & Blocks the actions of NFKB in the nucleus & [110] \\
\hline
\end{tabular}

particularly interesting as CXADR was recently shown to induce stress-activated MAPK pathways in the heart that result in increased production of IFN $\gamma$, IL-12, IL$1 \beta$, TNF $\alpha$, and IL-6 [101] as well as changes in tight junction in cardiac vasculature [113]. Increased neural expression of CXADR and its induction of IL-1 $\beta$ and MAPK could contribute to reported MAPK-p38-dependent hyperphosphorylation of tau and tangle formation [31,42].

\section{ADAMTS1 and ADAMTS5}

IL-1 $\beta$ induces synthesis of two other chromosome 21 genes that encode two secreted proteinases of the ADAMTS gene family (ADAMTS1 and ADAMTS5) [102,103,114] that degrade extracellular matrix proteins. This interaction between IL-1 $\beta$ and these proteinases may explain, at least in part, the dramatic overexpression of ADAMTS1 in DS [115]. Moreover, such excessive expression of these proteinases in DS may contribute to degradation of extracellular matrix proteoglycans such as aggrecan and versican in DS $[116,117]$.

\section{TIAM1}

The chromosome 21 gene for T-cell lymphoma invasion and metastasis-1 (TIAM1) is a critical regulatory factor in IL-1 $\beta$-induced synthesis of NADPH oxidase [104], via induction of guanine nucleotide exchange factor for Rac1 [118] that contributes to the activation of Rac1 for the activation of NADPH oxidase [119] in pancreatic $\beta$-cells. By analogy, simultaneous excess expression of TIAM1 and IL- 1 in DS brain $[17,120]$ may contribute to the dramatic oxidative stress in DS brain [121].

\section{SOD1}

Superoxide dismutase 1 (SOD1) is a potent endogenous neural-relevant copper and zinc binding enzyme that is encoded on chromosome 21 [105] and acts as a soluble cytoplasmic and mitochondrial interspace protein that converts superoxide radicals to molecular oxygen and hydrogen peroxide [122]. Although the SOD1 gene is most commonly associated with anterolateral sclerosis (ALS) as mutation in SOD1 are linked with genetic susceptibility to ALS [123,124]. However, overexpression of non-mutated SOD1 in the absence of a peroxidedetoxifying enzyme in the same cellular compartment promotes oxidative stress [125], suggesting that the elevation of SOD1 due to trisomy 21, if unmatched by increases in the levels of peroxide-detoxifying enzyme, would be detrimental [126].

\section{IFNAR1, IFNAR2, and IFNGR2}

As the genes encoding the receptors for IFN $\alpha 1$ and 2 , and for IFN- $\gamma$ (IFNAR1, IFNAR2, and IFNGR2) are located on chromosome $21[106,107]$ and are therefore all subject to triplication in trisomy 21 . IFNAR1 and IFNAR2 respond 
to IFN $\alpha, \beta$, or $\gamma$ and, upon ligand binding, activate the signaling pathway for induction of proinflammatory cytokines, including IL-1 $\beta, T N F \alpha$, and IL-6 expression [127]. IFNGR2 uses the same signaling pathway but uniquely responds to IFN $\gamma$. In the trisomy 16 mouse model of DS, both the IFNGR2 and IFNAR2 are triplicated. Studies in these mice, which develop significant pathology in utero and rarely survive to birth, show that treatment of trisomy 16 fetuses with anti-IFN IgG improves the mouse phenotype, suggesting that the triplication of the IFN receptors significantly contributes to the lethal pathology present in these mice [128]. Furthermore, a partial knockout of IFNAR2 and IFNGR2 improves growth and viability of cultured neurons derived from trisomy 16 mouse fetuses [129]. Therefore, the expected hyper-responsiveness to IFN in individuals with DS may contribute to the elevated inflammatory profile in the brain as well as systemically.

\section{RIPK4}

Receptor-interacting serine-threonine kinase 4 (RIPK4) is a protein kinase involved in multiple cell signaling pathways. One of these pathways is the signaling pathway for the activation of NFKB $[130,131]$, which is important in promoting proinflammatory cytokines such as TNF $\alpha$ [132]. In addition, RIPK4 is involved in the signaling cascade of the TNF $\alpha$ receptor TNFR1 [108]. It is important to note that TNFR1 is most heavily implicated in the toxic effects of TNF $\alpha$, suggesting that overexpression of RIPK4 increases responsiveness of TNFR1 to TNF $\alpha$, exacerbating the effects of TNFR1.

\section{CBS}

The chromosome 21 gene product cystathionine beta synthase (CBS) [109] is a cytosolic enzyme that catalyzes the desulfhydration of cysteine for production of hydrogen sulfide, which is now recognized as an atypical cellular messenger that is important in both normal [133] and abnormal cellular functions [134]. Hydrogen sulfide is a complicated signaling molecule with an apparent bimodal action on inflammation, in that low levels appear to be anti-inflammatory, while high levels appear to exacerbate neuroinflammatory processes (for review please see $[135,136])$. Overexpression of CBS in trisomy 21 and its relation to development of $\mathrm{AD}$ in $\mathrm{DS}$ is, at present, unknown.

\section{PRMT2}

The enzyme, protein arginine methyltransferase 2 (PRMT2), facilitates the methylation of arginine necessary for regulation of the JAK/STAT signaling pathway, which leads to elevation of expression of neuroinflammatory cytokines IFN $\gamma$, IFN $\alpha$, and IL-6 [137] and via inhibition of NFKB may promote [110] apoptosis. Importantly, degradation of proteins containing methylated arginine results in the production of asymmetric dimethylarginine (ADMA) [138], inhibition of nitric oxide synthase activity, and decreased levels of nitric oxide (NO) [139]. If there is an increase in tissue levels of ADMA in DS brain, as there is in the plasma of DS patients with pulmonary hypertension [140], brain levels of NO may be decreased, the JAKSTAT pathway increased, and changes occur toward the inflammatory state of microglia.

\section{Summary}

The principal conclusion one may draw from information presented here regarding the influence of triplication of chromosome 21 genes on neuropathogenesis and development of the clinical and neuropathological manifestations of $\mathrm{AD}$ and $\mathrm{AD}$ in $\mathrm{DS}$ is that many chromosome 21 genes upregulate classical neural immune responses of activated microglia, which are now classified according to systemic immune macrophage profiles as either classical M1 responses that favor overexpression of pro-inflammatory cytokines, or alternative M2 responses that favor overexpression of anti-inflammatory cytokines. As so many chromosome 21 genes are primarily associated with M1, that is, proinflammatory responses, we propose that $M 1$ is the principle glial activation state that will be observed in the DS brain. This is commonsensical as, for example in experimental conditions, triplication of the major IFN

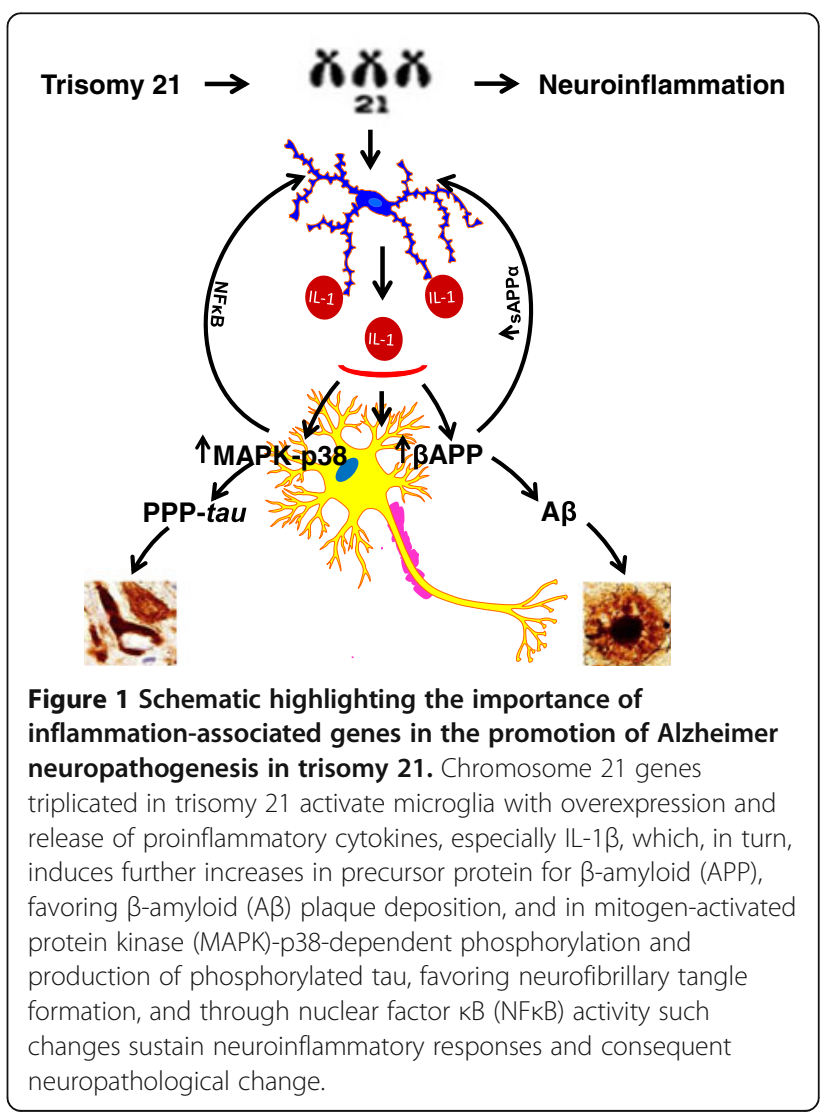


receptor genes IFNAR1, IFNAR2 and IFNGR2 is associated with enhancement of interferon signaling and TIAM1, SOD1, and PRMT2 are associated with increases in oxidative stresses, and S100B induces expression of APP as well as IL- $1 \alpha$ and $\beta$. Moreover, in brains of fetuses, neonates, children, and adults with DS, astrocytes are activated and express excess levels of S100B adjacent to activated microglia overexpressing IL- $1 \alpha$ and neurons overexpressing APP. These findings, together with triplication of the $\beta A P P$ gene in DS and experimental evidence of neuronal stress-induced increases in $\beta$ APP expression and parallel secretion of sAPP for resultant activation of microglia, evidenced by increases in oxidative markers and overexpression and release of IL-1 $\beta$, suggest that triplication of chromosome 21 genes, perhaps especially $\beta A P P$, may account for most of the very early neuroinflammatory and oxidative changes in DS. By analogy, the neuronal stress triggered by the many risk factors that favor development of $\mathrm{AD}$, manifested as neuronal overexpression of APP and release of SAPP, may be prime in inducing the dramatic neuroinflammatory responses that then result in a selfamplifying cycle (Figure 1) of increasing neuropathological changes, including neuronal stress, neuroinflammation, and synthesis of the precursors giving rise to formation of the $\mathrm{A} \beta$ plaques and neurofibrillary tangles diagnostic of $\mathrm{AD}$.

Relative to other causative factors in individuals at increased risk for development of $\mathrm{AD}$ - the small population of individuals with mutations in $A \beta$-associated genes - trisomy 21 represents the population (one in every seven-hundred and thirty-three live births) with the highest incidence of $\mathrm{AD}$, suggesting that greater attention should be given to investigating DS pathogenesis as it relates to sporadic AD. Such studies could well be directed toward not only discovery of basic molecular mechanisms driven by chromosome 21 gene products but also toward development of rational therapeutic approaches to treatments that may delay onset or slow the progression of $\mathrm{AD}$, thus preserving cognitive functions not only in $\mathrm{DS}$ but also in $\mathrm{AD}$ itself.

\footnotetext{
Abbreviations

A $\beta$ : $\beta$-amyloid; AD: Alzheimer's disease; ADMA: Asymmetric dimethylarginine; ALS: Anterolateral sclerosis; APP: Precursor protein of $\beta$-amyloid; APP: Precursor protein; BACE2: $\beta$-amyloid cleavage enzyme 2 ; CBS: Cystathionine beta synthase; CNS: Central nervous system; DS: Down's syndrome; DSCR: Down's syndrome critical region; IL: Interleukin; IFN: Interferon; IL1-R2: Interleukin 1 receptor 2; IgG: Immunoglobulin; JAK: Janus kinase; JNK: c-Jun N-terminal kinase; MAPK: Mitogen-activated protein kinase; MHC: Major histocompatibility complex; MRI: Magnetic resonance imaging; PRMT2: Protein arginine methyltransferase 2; NAPDH: Nicotinamide adenine dinucleotide phosphate-oxidase; NF-kB: Nuclear factor-kappa B; NO: Nitric oxide; PRMT2: Protein arginine methyltransferase 2; RIPK4: Receptor-interacting serine-threonine kinase 4; SOD1: Superoxide dismutase 1; STAT: Signal transducer and activator of transcription; TIAM1: T-cell lymphoma invasion and metastasis-1 TGF, Transforming growth factor; TNF: Tumor necrosis factor.
}

\section{Competing interests}

The authors declare that they have no competing interests.

\section{Authors' contributions}

MW and WSTG, contributed equally to the writing of this review. Both authors read and approved the final manuscript.

\section{Acknowledgements}

The authors thank Dr. Orwa Aboud for critical review of the manuscript. WSTG supported in part by NIH/NIA AG12411 and the Windgate Foundation. DMW supported in part by NS079637 and P20GM103486.

\section{Author details}

'Department of Physiology, Sanders-Brown Center on Aging, University of Kentucky, Lexington, KY 40536, USA. ${ }^{2}$ Donald W. Reynolds Department of Geriatrics, Donald W. Reynolds Institute on Aging, University of Arkansas for Medical Sciences, 629 Jack Stephens Dr., Little Rock, AR 72205, USA. ${ }^{3}$ The Geriatric Research Education Clinical Center, Central Arkansas HealthCare System, Little Rock, AR, USA.

Received: 22 March 2013 Accepted: 28 May 2013

Published: 16 July 2013

\section{References}

1. Canfield MA, Ramadhani TA, Yuskiv N, Davidoff MJ, Petrini JR, Hobbs CA, Kirby RF, Romitti PA, Collins JS, Devine O, Honein MA, Mai CT, Edmonds LD, Correa A: Improved national prevalence estimates for 18 selected major birth defects-United States, 1999-2001. MMWR Morb Mortal Wkly Rep 2006, 54:1301-1305.

2. Yang Q, Rasmussen SA, Friedman JM: Mortality associated with Down's syndrome in the USA from 1983 to 1997: a population-based study. Lancet 2002, 359:1019-1025.

3. Canfield MA, Honein MA, Yuskiv N, Xing J, Mai CT, Collins JS, Devine O, Petrini J, Ramadhani TA, Hobbs CA, Kirby RS: National estimates and race/ ethnic-specific variation of selected birth defects in the United States, 1999-2001. Birth Defects Res A Clin Mol Teratol 2006, 76:747-756.

4. Lander ES, Linton LM, Birren B, Nusbaum C, Zody MC, Baldwin J, Devon K, Dewar K, Doyle M, FitzHugh W, Funke R, Gage D, Harris K, Heaford A, Howland J, Kann L, Lehoczky J, LeVine R, McEwan P, McKernan K, Meldrim J, Mesirov JP, Miranda C, Morris W, Naylor J, Raymond C, Rosetti M, Santos R, Sheridan A, Sougnez C, et al: Initial sequencing and analysis of the human genome. Nature 2001, 409:860-921.

5. van Trotsenburg AS, Heymans HS, Tijssen JG, de Vijlder JJ, Vulsma T: Comorbidity, hospitalization, and medication use and their influence on mental and motor development of young infants with Down syndrome. Pediatrics 2006, 118:1633-1639.

6. Leverenz JB, Raskind MA: Early amyloid deposition in the medial temporal lobe of young Down syndrome patients: a regional quantitative analysis. Exp Neurol 1998, 150:296-304.

7. Burger PC, Vogel FS: The development of the pathologic changes of Alzheimer's disease and senile dementia in patients with Down's syndrome. Am J Pathol 1973, 73:457-476.

8. Hof PR, Bouras C, Perl DP, Sparks DL, Mehta N, Morrison JH: Age-related distribution of neuropathologic changes in the cerebral cortex of patients with Down's syndrome. Quantitative regional analysis and comparison with Alzheimer's disease. Arch Neurol 1995, 52:379-391.

9. Olson Ml, Shaw CM: Presenile dementia and Alzheimer's disease in mongolism. Brain 1969, 92:147-156.

10. Oliver C, Crayton L, Holland A, Hall S, Bradbury J: A four year prospective study of age-related cognitive change in adults with Down's syndrome. Psychol Med 1998, 28:1365-1377.

11. Lai F, Williams RS: A prospective study of Alzheimer disease in Down syndrome. Arch Neurol 1989, 46:849-853.

12. Johannsen $P$, Christensen JE, Mai J: The prevalence of dementia in Down syndrome. Dementia 1996, 7:221-225.

13. Janicki MP, Dalton AJ: Prevalence of dementia and impact on intellectual disability services. Ment Retard 2000, 38:276-288.

14. Wisniewski KE, Dalton AJ, McLachlan C, Wen GY, Wisniewski HM Alzheimer's disease in Down's syndrome: clinicopathologic studies. Neurology 1985, 35:957-961.

15. Lott IT, Head E: Down syndrome and Alzheimer's disease: a link between development and aging. Ment Retard Dev Disabil Res Rev 2001, 7:172-178. 
16. Tanzi RE, McClatchey Al, Lamperti ED, Villa-Komaroff L, Gusella JF, Neve RL: Protease inhibitor domain encoded by an amyloid protein precursor mRNA associated with Alzheimer's disease. Nature 1988, 331:528-530.

17. Griffin WS, Stanley LC, Ling C, White L, MacLeod V, Perrot LJ, White CL III, Araoz C: Brain interleukin 1 and S-100 immunoreactivity are elevated in Down syndrome and Alzheimer disease. Proc Natl Acad Sci USA 1989, 86:7611-7615

18. Webb AC, Collins KL, Auron PE, Eddy RL, Nakai H, Byers MG, Haley LL, Henry WM, Shows TB: Interleukin-1 gene (IL1) assigned to long arm of human chromosome 2. Lymphokine Res 1986, 5:77-85.

19. D'Eustachio P, Jadidi S, Fuhlbrigge RC, Gray PW, Chaplin DD: Interleukin-1 alpha and beta genes: linkage on chromosome 2 in the mouse. Immunogenetics 1987, 26:339-343.

20. Barger SW, Harmon AD: Microglial activation by Alzheimer amyloid precursor protein and modulation by apolipoprotein E. Nature 1997 388:878-881.

21. Goldgaber D, Harris HW, Hla T, Maciag T, Donnelly RJ, Jacobsen JS, Vitek MP, Gajdusek DC: Interleukin 1 regulates synthesis of amyloid beta-protein precursor mRNA in human endothelial cells. Proc Natl Acad Sci USA 1989 86:7606-7610

22. Liu L, Li Y, Van Eldik LJ, Griffin WS, Barger SW: S100B-induced microglial and neuronal IL-1 expression is mediated by cell type-specific transcription factors. J Neurochem 2005, 92:546-553.

23. Sheng JG, Ito K, Skinner RD, Mrak RE, Rovnaghi CR, Van Eldik LJ, Griffin WS: In vivo and in vitro evidence supporting a role for the inflammatory cytokine interleukin-1 as a driving force in Alzheimer pathogenesis. Neurobiol Aging 1996, 17:761-766.

24. Mrak RE: Neuropathology and the neuroinflammation idea. J Alzheimers Dis 2009, 18:473-481

25. Royston MC, McKenzie JE, Gentleman SM, Sheng JG, Mann DM, Griffin WS, Mrak RE: Overexpression of s100beta in Down's syndrome: correlation with patient age and with beta-amyloid deposition. Neuropathol Appl Neurobiol 1999, 25:387-393.

26. Donnelly RJ, Jacobsen JS, Rasool CG, Blume AJ, Vitek MP: Isolation and expression of multiple forms of beta amyloid protein precursor cDNAs. Prog Clin Biol Res 1989, 317:925-937.

27. Li Y, Wang J, Sheng JG, Liu L, Barger SW, Jones RA, Van Eldik L, Mrak RE, Griffin WS: S100 beta increases levels of beta-amyloid precursor protein and its encoding mRNA in rat neuronal cultures. J Neurochem 1998, 71:1421-1428.

28. Li Y, Liu L, Kang J, Sheng JG, Barger SW, Mrak RE, Griffin WS: Neuronal-glia interactions mediated by interleukin-1 enhance neuronal acetylcholinesterase activity and mRNA expression. J Neurosci 2000, 20:149-155.

29. Liu L, Aboud O, Jones RA, Mrak RE, Griffin WS, Barger SW: Apolipoprotein E expression is elevated by interleukin 1 and other interleukin 1-induced factors. J Neuroinflammation 2011, 8:175.

30. Sheng JG, Mrak RE, Griffin WS: Neuritic plaque evolution in Alzheimer's disease is accompanied by transition of activated microglia from primed to enlarged to phagocytic forms. Acta Neuropathol (Berl) 1997, 94:1-5.

31. Li Y, Liu L, Barger SW, Griffin WS: Interleukin-1 mediates pathological effects of microglia on tau phosphorylation and on synaptophysin synthesis in cortical neurons through a p38-MAPK pathway. J Neurosc 2003, 23:1605-1611.

32. Griffin WS, Mrak RE: Interleukin-1 in the genesis and progression of and risk for development of neuronal degeneration in Alzheimer's disease. $J$ Leukoc Biol 2002, 72:233-238.

33. Griffin WS, Sheng JG, Gentleman SM, Graham DI, Mrak RE, Roberts GW: Microglial interleukin-1 alpha expression in human head injury: correlations with neuronal and neuritic beta-amyloid precursor protein expression. Neurosci Lett 1994, 176:133-136.

34. Sheng JG, Boop FA, Mrak RE, Griffin WS: Increased neuronal beta-amyloid precursor protein expression in human temporal lobe epilepsy: association with interleukin-1 alpha immunoreactivity. J Neurochem 1994, 63:1872-1879

35. Griffin WS, Yeralan O, Sheng JG, Boop FA, Mrak RE, Rovnaghi CR, Burnett BA Feoktistova A, Van Eldik L: Overexpression of the neurotrophic cytokine S100 beta in human temporal lobe epilepsy. J Neurochem 1995, 65:228-233

36. Aboud O, Mrak RE, Boop F, Griffin ST: Apolipoprotein epsilon3 alleles are associated with indicators of neuronal resilience. BMC Med 2012, 10:35.
37. Sheng JG, Griffin WS, Royston MC, Mrak RE: Distribution of interleukin-1 -immunoreactive microglia in cerebral cortical layers: implications for neuritic plaque formation in Alzheimer's disease. Neuropathol Appl Neurobiol 1998, 24:278-283.

38. Sheng JG, Mrak RE, Griffin WS: Microglial interleukin-1 alpha expression in brain regions in Alzheimer's disease: correlation with neuritic plaque distribution. Neuropathol App/ Neurobiol 1995, 21:290-301.

39. Stanley LC, Mrak RE, Woody RC, Perrot LJ, Zhang S, Marshak DR, Nelson SJ, Griffin WS: Glial cytokines as neuropathogenic factors in HIV infection: pathogenic similarities to Alzheimer's disease. J Neuropathol Exp Neurol 1994, 53:231-238

40. Barger SW, DeWall KM, Liu L, Mrak RE, Griffin WS: Relationships between expression of apolipoprotein $\mathrm{E}$ and beta-amyloid precursor protein are altered in proximity to Alzheimer beta-amyloid plaques: potential explanations from cell culture studies. J Neuropathol Exp Neurol 2008 67:773-783

41. Mrak RE, Sheng JG, Griffin WS: Correlation of astrocytic S100 beta expression with dystrophic neurites in amyloid plaques of Alzheimer's disease. J Neuropathol Exp Neurol 1996, 55:273-279.

42. Sheng JG, Zhu SG, Jones RA, Griffin WS, Mrak RE: Interleukin-1 promotes expression and phosphorylation of neurofilament and tau proteins in vivo. Exp Neurol 2000, 163:388-391.

43. Sheng JG, Jones RA, Zhou XQ, McGinness JM, Van Eldik LJ, Mrak RE, Griffin WS: Interleukin-1 promotion of MAPK-p38 overexpression in experimental animals and in Alzheimer's disease: potential significance for tau protein phosphorylation. Neurochem Int 2001, 39:341-348.

44. Levin ED, Briggs SJ, Christopher NC, Auman JT: Working memory performance and cholinergic effects in the ventral tegmental area and substantia nigra. Brain Res 1994, 657:165-170.

45. Whitehouse PJ, Price DL, Struble RG, Clark AW, Coyle JT, Delon MR: Alzheimer's disease and senile dementia: loss of neurons in the basal forebrain. Science 1982, 215:1237-1239.

46. Whitehouse PJ, Martino AM, Marcus KA, Zweig RM, Singer HS, Price DL, Kellar KJ: Reductions in acetylcholine and nicotine binding in several degenerative diseases. Arch Neurol 1988, 45:722-724.

47. Coleman PD, Yao PJ: Synaptic slaughter in Alzheimer's disease. Neurobiol Aging 2003, 24:1023-1027.

48. Callahan LM, Vaules WA, Coleman PD: Progressive reduction of synaptophysin message in single neurons in Alzheimer disease. $J$ Neuropathol Exp Neurol 2002, 61:384-395.

49. Griffin WS, Barger SW: Neuroinflammatory cytokines-the common thread in Alzheimer's pathogenesis. US Neurol 2010, 6(2):19-27.

50. Pessac B, Godin I, Alliot F: Microglia: origin and development. Bull Acad Natl Med 2001, 185:337-346. discussion 346-337.

51. Perry VH, Gordon S: Macrophages and microglia in the nervous system. Trends Neurosci 1988, 11:273-277.

52. Ling EA: Some aspects of amoeboid microglia in the corpus callosum and neighbouring regions of neonatal rats. J Anat 1976, 121(Pt 1):29-45.

53. Colton CA, Wilcock DM: Assessing activation states in microglia. CNS Neurol Disord Drug Targets 2010, 9:174-191.

54. McGeer PL, Itagaki S, Tago H, McGeer EG: Reactive microglia in patients with senile dementia of the Alzheimer type are positive for the histocompatibility glycoprotein HLA-DR. Neurosci Lett 1987, 79:195-200.

55. Perlmutter LS, Scott SA, Barron E, Chui HC: MHC class II-positive microglia in human brain: association with Alzheimer lesions. J Neurosci Res 1992, 33:549-558.

56. Xiang Z, Haroutunian V, Ho L, Purohit D, Pasinetti GM: Microglia activation in the brain as inflammatory biomarker of Alzheimer's disease neuropathology and clinical dementia. Dis Markers 2006, 22:95-102.

57. Sheng JG, Mrak RE, Griffin WS: Glial-neuronal interactions in Alzheimer disease: progressive association of IL-1alpha + microglia and S100beta + astrocytes with neurofibrillary tangle stages. J Neuropathol Exp Neurol 1997, 56:285-290.

58. Anneren G, Edman B: Down syndrome-a gene dosage disease caused by trisomy of genes within a small segment of the long arm of chromosome 21, exemplified by the study of effects from the superoxide-dismutase type 1 (SOD-1) gene. APMIS Supp/ 1993, 40:71-79.

59. Rahmani Z, Blouin JL, Creau-Goldberg N, Watkins PC, Mattei JF, Poissonnier M, Prieur M, Chettouh Z, Nicole A, Aurias A, Sinet P-M, Delabar J-M: Critical role of the D21S55 region on chromosome 21 in the pathogenesis of Down syndrome. Proc Natl Acad Sci USA 1989, 86:5958-5962. 
60. Sinet PM, Theophile D, Rahmani Z, Chettouh Z, Blouin JL, Prieur M, Noel B, Delabar JM: Mapping of the Down syndrome phenotype on chromosome 21 at the molecular level. Biomed Pharmacother 1994, 48:247-252.

61. Tanzi RE, Gusella JF, Watkins PC, Bruns GA, St George-Hyslop P, Van Keuren ML, Patterson D, Pagan S, Kurnit DM, Neve RL: Amyloid beta protein gene: cDNA, mRNA distribution, and genetic linkage near the Alzheimer locus. Science 1987, 235:880-884.

62. Glenner GG, Wong CW, Quaranta V, Eanes ED: The amyloid deposits in Alzheimer's disease: their nature and pathogenesis. Appl Pathol 1984, 2:357-369.

63. Glenner GG, Wong CW: Alzheimer's disease and Down's syndrome: sharing of a unique cerebrovascular amyloid fibril protein. Biochem Biophys Res Commun 1984, 122:1131-1135.

64. Margallo-Lana M, Morris CM, Gibson AM, Tan AL, Kay DW, Tyrer SP, Moore BP, Ballard CG: Influence of the amyloid precursor protein locus on dementia in Down syndrome. Neurology 2004, 62:1996-1998.

65. Rumble B, Retallack R, Hilbich C, Simms G, Multhaup G, Martins R, Hockey A, Montgomery P, Beyreuther K, Masters CL: Amyloid A4 protein and its precursor in Down's syndrome and Alzheimer's disease. N Engl J Med 1989, 320:1446-1452.

66. Sleegers K, Brouwers N, Gijselinck I, Theuns J, Goossens D, Wauters J, DelFavero J, Cruts M, van Duijn CM, Van Broeckhoven C: APP duplication is sufficient to cause early onset Alzheimer's dementia with cerebral amyloid angiopathy. Brain 2006, 129(Pt 11):2977-2983.

67. Rovelet-Lecrux A, Hannequin D, Raux G, Le Meur N, Laquerriere A, Vital A, Dumanchin C, Feuillette S, Brice A, Vercelletto M, Dubas F, Frebourg T: APP locus duplication causes autosomal dominant early-onset Alzheimer disease with cerebral amyloid angiopathy. Nat Genet 2006, 38:24-26.

68. Hardy JA, Higgins GA: Alzheimer's disease: the amyloid cascade hypothesis. Science 1992, 256:184-185.

69. Prasher VP, Farrer MJ, Kessling AM, Fisher EM, West RJ, Barber PC, Butler AC Molecular mapping of Alzheimer-type dementia in Down's syndrome. Ann Neurol 1998, 43:380-383.

70. Lott IT: Neurological phenotypes for Down syndrome across the life span. Prog Brain Res 2012, 197:101-121.

71. St George-Hyslop PH, Tanzi RE, Polinsky RJ, Haines JL, Nee L, Watkins P, Myers RH, Feldman RG, Pollen D, Drachman D, Growden J, Bruni A, Foncin JF, Salmon D, Frommelt P, Amaducci L, Sorbi S, Piacentini S, Stewart GD, Hobbs WJ, Conneally PM, Gusella JF: The genetic defect causing familial Alzheimer's disease maps on chromosome 21. Science 1987, 235:885-890.

72. Acquati F, Accarino M, Nucci C, Fumagalli P, Jovine L, Ottolenghi S, Taramelli R: The gene encoding DRAP (BACE2), a glycosylated transmembrane protein of the aspartic protease family, maps to the down critical region. FEBS Lett 2000, 468:59-64.

73. Zhou S, Zhou H, Walian PJ, Jap BK: CD147 is a regulatory subunit of the gamma-secretase complex in Alzheimer's disease amyloid beta-peptide production. Proc Natl Acad Sci U S A 2005, 102:7499-7504.

74. Cheon MS, Dierssen M, Kim SH, Lubec G: Protein expression of BACE1, BACE2 and APP in Down syndrome brains. Amino Acids 2008, 35:339-343.

75. Anderson JP, Chen Y, Kim KS, Robakis NK: An alternative secretase cleavage produces soluble Alzheimer amyloid precursor protein containing a potentially amyloidogenic sequence. J Neurochem 1992, 59:2328-2331.

76. Lannfelt L, Basun H, Wahlund LO, Rowe BA, Wagner SL: Decreased alphasecretase-cleaved amyloid precursor protein as a diagnostic marker for Alzheimer's disease. Nat Med 1995, 1:829-832.

77. Gandy S, Greengard P: Regulated cleavage of the Alzheimer amyloid precursor protein: molecular and cellular basis. Biochimie 1994, 76:300-303.

78. Barger SW, Mattson MP: Participation of gene expression in the protection against amyloid beta-peptide toxicity by the beta-amyloid precursor protein. Ann NY Acad Sci 1996, 777:303-309.

79. Kuhn PH, Marjaux E, Imhof A, De Strooper B, Haass C, Lichtenthaler SF: Regulated intramembrane proteolysis of the interleukin-1 receptor II by alpha-, beta-, and gamma-secretase. J Biol Chem 2007, 282:11982-11995.

80. Allore RJ, Friend WC, O'Hanlon D, Neilson KM, Baumal R, Dunn RJ, Marks A: Cloning and expression of the human S100 beta gene. J Biol Chem 1990, 265:15537-15543.

81. Haglid KG, Hansson HA, Ronnback L: S-100 in the central nervous system of rat, rabbit and guinea pig during postnatal development. Brain Res 1977, 123:331-345.
82. Donato R, Cannon BR, Sorci G, Riuzzi F, Hsu K, Weber DJ, Geczy CL: Functions of S100 proteins. Curr Mol Med 2013, 13:24-57.

83. Kligman D, Marshak DR: Purification and characterization of a neurite extension factor from bovine brain. Proc Natl Acad Sci USA 1985, 82:7136-7139.

84. Barger SW, Van Eldik LJ, Mattson MP: S100 beta protects hippocampal neurons from damage induced by glucose deprivation. Brain Res 1995 677:167-170.

85. Marshak DR: S100 beta as a neurotrophic factor. Prog Brain Res 1990, 86:169-181.

86. Reeves RH, Yao J, Crowley MR, Buck S, Zhang X, Yarowsky P, Gearhart JD, Hilt DC: Astrocytosis and axonal proliferation in the hippocampus of S100b transgenic mice. Proc Natl Acad Sci USA 1994, 91:5359-5363.

87. Marshak DR, Pesce SA, Stanley LC, Griffin WS: Increased S100 beta neurotrophic activity in Alzheimer's disease temporal lobe. Neurobiol Aging 1992, 13:1-7.

88. Mrak RE, Griffin WS: The role of activated astrocytes and of the neurotrophic cytokine S100B in the pathogenesis of Alzheimer's disease. Neurobiol Aging 2001, 22:915-922.

89. Azmitia EC, Griffin WS, Marshak DR, Van Eldik LJ, Whitaker-Azmitia PM: S100 beta and serotonin: a possible astrocytic-neuronal link to neuropathology of Alzheimer's disease. Prog Brain Res 1992, 94:459-473.

90. Foerch C, Otto B, Singer OC, Neumann-Haefelin T, Yan B, Berkefeld J, Steinmetz H, Sitzer M: Serum S100B predicts a malignant course of infarction in patients with acute middle cerebral artery occlusion. Stroke 2004, 35:2160-2164.

91. Foerch C, Singer OC, Neumann-Haefelin T, du Mesnil de Rochemont R, Steinmetz $H$, Sitzer M: Evaluation of serum S100B as a surrogate marker for long-term outcome and infarct volume in acute middle cerebral artery infarction. Arch Neurol 2005, 62:1130-1134.

92. Foerch C, Wunderlich MT, Dvorak F, Humpich M, Kahles T, Goertler M, Alvarez-Sabin J, Wallesch CW, Molina CA, Steinmetz H, Sitzer M, Montaner J: Elevated serum S100B levels indicate a higher risk of hemorrhagic transformation after thrombolytic therapy in acute stroke. Stroke 2007 , 38:2491-2495

93. Stein DM, Lindell AL, Murdock KR, Kufera JA, Menaker J, Bochicchio GV, Aarabi B, Scalea TM: Use of serum biomarkers to predict cerebral hypoxia after severe traumatic brain injury. J Neurotrauma 2012, 29:1140-1149.

94. Neselius S, Brisby H, Theodorsson A, Blennow K, Zetterberg H, Marcusson J: CSF-biomarkers in Olympic boxing: diagnosis and effects of repetitive head trauma. PloS One 2012, 7:e33606.

95. Tavarez MM, Atabaki SM, Teach SJ: Acute evaluation of pediatric patients with minor traumatic brain injury. Curr Opin Pediatr 2012, 24:307-313.

96. Strauss Gl, Christiansen M, Moller K, Clemmesen JO, Larsen FS, Knudsen GM: S-100b and neuron-specific enolase in patients with fulminant hepatic failure. Liver Transp/ 2001, 7:964-970.

97. Kimura T, Budka H: Glial fibrillary acidic protein and S-100 protein in human hepatic encephalopathy: immunocytochemical demonstration of dissociation of two glia-associated proteins. Acta Neuropathol 1986, 70:17-21.

98. Mrak RE, Griffin WS: Trisomy 21 and the brain. J Neuropathol Exp Neurol 2004, 63:679-685.

99. Schmechel DE, Goldgaber D, Burkhart DS, Gilbert JR, Gajdusek DC, Roses AD: Cellular localization of messenger RNA encoding amyloid-beta-protein in normal tissue and in Alzheimer disease. Alzheimer Dis Assoc Disord 1988, 2:96-111.

100. Griffin WS, Ling C, White CL III, Morrison-Bogorad M: Polyadenylated messenger RNA in paired helical filament-immunoreactive neurons in Alzheimer disease. Alzheimer Dis Assoc Disord 1990, 4:69-78.

101. Yuen S, Smith J, Caruso L, Balan M, Opavsky MA: The coxsackie-adenovirus receptor induces an inflammatory cardiomyopathy independent of viral infection. J Mol Cell Cardiol 2011, 50:826-840.

102. Kuno K, Kanada N, Nakashima E, Fujiki F, Ichimura F, Matsushima K: Molecular cloning of a gene encoding a new type of metalloproteinasedisintegrin family protein with thrombospondin motifs as an inflammation associated gene. J Biol Chem 1997, 272:556-562.

103. Yamanishi Y, Boyle DL, Clark M, Maki RA, Tortorella MD, Arner EC, Firestein GS: Expression and regulation of aggrecanase in arthritis: the role of TGF-beta. J Immunol 2002, 168:1405-1412.

104. Subasinghe W, Syed I, Kowluru A: Phagocyte-like NADPH oxidase promotes cytokine-induced mitochondrial dysfunction in pancreatic beta-cells: evidence for regulation by Rac1. Am J Physiol Regul Integr Comp Physiol 2011, 300:R12-R20. 
105. Danciger E, Dafni N, Bernstein Y, Laver-Rudich Z, Neer A, Groner Y: Human $\mathrm{Cu} / \mathrm{Zn}$ superoxide dismutase gene family: molecular structure and characterization of four $\mathrm{Cu} / \mathrm{Zn}$ superoxide dismutase-related pseudogenes. Proc Natl Acad Sci USA 1986, 83:3619-3623.

106. Kim SH, Cohen B, Novick D, Rubinstein M: Mammalian type I interferon receptors consists of two subunits: IFNaR1 and IFNaR2. Gene 1997, 196:279-286.

107. Boselli D, Ragimbeau J, Orlando L, Cappello P, Capello M, Ambrogio C, Chiarle R, Marsili G, Battistini A, Giovarelli M, Pellegrini S, Novelli F: Expression of IFNgammaR2 mutated in a dileucine internalization motif reinstates IFNgamma signaling and apoptosis in human T lymphocytes. Immunol Lett 2010, 134:17-25.

108. Rountree RB, Willis CR, Dinh H, Blumberg H, Bailey K, Dean C Jr, Peschon JJ, Holland PM: RIP4 regulates epidermal differentiation and cutaneous inflammation. J Invest Dermatol 2010, 130:102-112.

109. Sen U, Givvimani S, Abe OA, Lederer ED, Tyagi SC: Cystathionine betasynthase and cystathionine gamma-lyase double gene transfer ameliorate homocysteine-mediated mesangial inflammation through hydrogen sulfide generation. Am J Physiol Cell Physiol 2011, 300:C155-C163.

110. Ganesh L, Yoshimoto T, Moorthy NC, Akahata W, Boehm M, Nabel EG, Nabel GJ: Protein methyltransferase 2 inhibits NF-kappaB function and promotes apoptosis. Mol Cell Biol 2006, 26:3864-3874.

111. Tomko RP, Xu R, Philipson L: HCAR and MCAR: the human and mouse cellular receptors for subgroup $C$ adenoviruses and group $B$ coxsackieviruses. Proc Natl Acad Sci USA 1997, 94:3352-3356.

112. Ito M, Kodama M, Masuko M, Yamaura M, Fuse K, Uesugi $Y$, Hirono S, Okura Y, Kato K, Hotta Y, Honda T, Kuwano R, Aizawa Y: Expression of coxsackievirus and adenovirus receptor in hearts of rats with experimental autoimmune myocarditis. Circ Res 2000, 86:275-280.

113. Zen K, Liu Y, McCall IC, Wu T, Lee W, Babbin BA, Nusrat A, Parkos CA: Neutrophil migration across tight junctions is mediated by adhesive interactions between epithelial coxsackie and adenovirus receptor and a junctional adhesion molecule-like protein on neutrophils. Mol Biol Cell 2005, 16:2694-2703

114. Wei P, Zhao YG, Zhuang L, Hurst DR, Ruben S, Sang QX: Protein engineering and properties of human metalloproteinase and thrombospondin 1. Biochem Biophys Res Commun 2002, 293:478-488.

115. Miguel RF, Pollak A, Lubec G: Metalloproteinase ADAMTS-1 but not ADAMTS-5 is manifold overexpressed in neurodegenerative disorders as down syndrome, Alzheimer's and Pick's disease. Brain Res Mol Brain Res 2005, 133:1-5

116. Kuno K, Okada Y, Kawashima H, Nakamura H, Miyasaka M, Ohno H, Matsushima K: ADAMTS-1 cleaves a cartilage proteoglycan, aggrecan. FEBS Lett 2000, 478:241-245.

117. Tortorella MD, Liu RQ, Burn T, Newton RC, Arner E: Characterization of human aggrecanase 2 (ADAM-TS5): substrate specificity studies and comparison with aggrecanase 1 (ADAM-TS4). Matrix Biol 2002, 21:499-511.

118. Veluthakal R, Palanivel R, Zhao Y, McDonald P, Gruber S, Kowluru A: Ceramide induces mitochondrial abnormalities in insulin-secreting INS-1 cells: potential mechanisms underlying ceramide-mediated metabolic dysfunction of the beta cell. Apoptosis 2005, 10:841-850.

119. Hordijk PL: Regulation of NADPH oxidases: the role of Rac proteins. Circ Res 2006, 98:453-462.

120. Cheon MS, Kim SH, Yaspo ML, Blasi F, Aoki Y, Melen K, Lubec G: Protein levels of genes encoded on chromosome 21 in fetal Down syndrome brain: challenging the gene dosage effect hypothesis (Part I). Amino Acids 2003, 24:111-117

121. Lott IT, Head E, Doran E, Busciglio J: Beta-amyloid, oxidative stress and down syndrome. Curr Alzheimer Res 2006, 3:521-528.

122. Rakhit R, Chakrabartty A: Structure, folding, and misfolding of $\mathrm{Cu}, \mathrm{Zn}$ superoxide dismutase in amyotrophic lateral sclerosis. Biochim Biophys Acta 2006, 1762:1025-1037.

123. Rosen DR, Siddique T, Patterson D, Figlewicz DA, Sapp P, Hentati A, Donaldson D, Goto J, O'Regan JP, Deng HX, Rahmani Z, Krizus A, McKenna-Yasek D, Cayabyab A, Gaston SM, Berger R, Tanzi RE, Halperin JJ, Herzfeldt B, Van den Bergh R, Hung W-Y, Bird T, Deng G, Mulder DW, Smyth C, Laing NG, Soriano E, Pericak-Vance MA, Haines J, Rouleau GA, Gusella JS, Horvitz RH, Brown RH Jr: Mutations in $\mathrm{Cu} / \mathrm{Zn}$ superoxide dismutase gene are associated with familial amyotrophic lateral sclerosis. Nature 1993, 362:59-62.
124. Reaume AG, Elliott JL, Hoffman EK, Kowall NW, Ferrante RJ, Siwek DF, Wilcox HM, Flood DG, Beal MF, Brown RH Jr, Scott RW, Snider WD: Motor neurons in $\mathrm{Cu} / \mathrm{Zn}$ superoxide dismutase-deficient mice develop normally but exhibit enhanced cell death after axonal injury. Nat Genet 1996, 13:43-47.

125. Usui S, Oveson BC, Iwase T, Lu L, Lee SY, Jo YJ, Wu Z, Choi EY, Samulski RJ, Campochiaro PA: Overexpression of SOD in retina: need for increase in $\mathrm{H}$ (2)O(2)-detoxifying enzyme in same cellular compartment. Free Radic Biol Med 2011, 51:1347-1354.

126. Cenini G, Dowling AL, Beckett TL, Barone E, Mancuso C, Murphy MP, Levine H III, Lott IT, Schmitt FA, Butterfield DA, Head E: Association between frontal cortex oxidative damage and beta-amyloid as a function of age in Down syndrome. Biochim Biophys Acta 1822, 2012:130-138.

127. Park Jl, Strock CJ, Ball DW, Nelkin BD: Interleukin-1beta can mediate growth arrest and differentiation via the leukemia inhibitory factor/JAK/ STAT pathway in medullary thyroid carcinoma cells. Cytokine 2005, 29:125-134.

128. Maroun LE: Anti-interferon immunoglobulins can improve the trisomy 16 mouse phenotype. Teratology 1995, 51:329-335.

129. Maroun LE, Heffernan TN, Hallam DM: Partial IFN-alpha/beta and IFNgamma receptor knockout trisomy 16 mouse fetuses show improved growth and cultured neuron viability. J Interf Cytok Res 2000, 20:197-203.

130. Meylan E, Martinon F, Thome M, Gschwendt M, Tschopp J: RIP4 (DIK/PKK) a novel member of the RIP kinase family, activates NF-kappa B and is processed during apoptosis. EMBO Rep 2002, 3:1201-1208.

131. Dalal NV, Pranski EL, Tansey MG, Lah JJ, Levey Al, Betarbet RS: RNF11 modulates microglia activation through NF-kappaB signalling cascade. Neurosci Lett 2012, 528:174-179.

132. Albensi BC, Mattson MP: Evidence for the involvement of TNF and NF-kappaB in hippocampal synaptic plasticity. Synapse 2000, 35:151-159.

133. Baranano DE, Ferris CD, Snyder SH: Atypical neural messengers. Trends Neurosci 2001, 24:99-106.

134. Taoka S, Banerjee R: Characterization of NO binding to human cystathionine beta-synthase: possible implications of the effects of $\mathrm{CO}$ and NO binding to the human enzyme. J Inorg Biochem 2001, 87:245-251.

135. Li L, Bhatia M, Moore PK: Hydrogen sulphide-a novel mediator of inflammation? Curr Opin Pharmacol 2006, 6:125-129.

136. Whiteman M, Le Trionnaire S, Chopra M, Fox B, Whatmore J: Emerging role of hydrogen sulfide in health and disease: critical appraisal of biomarkers and pharmacological tools. Clin Sci 2011, 121:459-488.

137. Mowen KA, Tang J, Zhu W, Schurter BT, Shuai K, Herschman HR, David M: Arginine methylation of STAT1 modulates IFNalpha/beta-induced transcription. Cell 2001, 104:731-741.

138. McDermott JR: Studies on the catabolism of Ng-methylarginine, $\mathrm{Ng}$ $\mathrm{Ng}$-dimethylarginine and $\mathrm{Ng}, \mathrm{Ng}$-dimethylarginine in the rabbit. Biochem J 1976, 154:179-184

139. Vallance $P$, Leone A, Calver A, Collier J, Moncada S: Accumulation of an endogenous inhibitor of nitric oxide synthesis in chronic renal failure. Lancet 1992, 339:572-575.

140. Cua CL, Rogers LK, Chicoine LG, Augustine M, Jin Y, Nash PL, Nelin LD: Down syndrome patients with pulmonary hypertension have elevated plasma levels of asymmetric dimethylarginine. Eur J Pediatr 2011, 170:859-863.

doi:10.1186/1742-2094-10-84

Cite this article as: Wilcock and Griffin: Down's syndrome

neuroinflammation, and Alzheimer neuropathogenesis. Journal of Neuroinflammation 2013 10:84. 